\title{
The Meaning of Space in the Residence of Java - Tondano (Jaton) People in Minahasa Case: Residence Period of 1900-1950
}

\author{
Heryati $^{1^{*}}$, Muhammad Faqih ${ }^{2}$, Murni Rachmawati ${ }^{2}$, Arina Hayati ${ }^{2}$ \\ ${ }^{1}$ Department of Architecture, Faculty of Engineering, Universitas Negeri Gorontalo, 96128, Gorontalo, Indonesia \\ ${ }^{2}$ Department of Architecture, Institute of Technology Sepuluh Nopember, 60111, Surabaya, Indonesia
}

Received February 18, 2021; Revised August 27, 2021; Accepted September 21, 2021

\section{Cite This Paper in the following Citation Styles}

(a): [1] Heryati, Muhammad Faqih, Murni Rachmawati, Arina Hayati , "The Meaning of Space in the Residence of Java - Tondano (Jaton) People in Minahasa Case: Residence Period of 1900-1950," Civil Engineering and Architecture, Vol. 9, No. 6, pp. 1909-1919, 2021. DOI: 10.13189/cea.2021.090622.

(b): Heryati, Muhammad Faqih, Murni Rachmawati, Arina Hayati (2021). The Meaning of Space in the Residence of Java - Tondano (Jaton) People in Minahasa Case: Residence Period of 1900-1950. Civil Engineering and Architecture, 9(6), 1909-1919. DOI: 10.13189/cea.2021.090622.

Copyright $\subseteq 2021$ by authors, all rights reserved. Authors agree that this article remains permanently open access under the terms of the Creative Commons Attribution License 4.0 International License

\begin{abstract}
The understanding of the meaning of space differs among people with different background of culture. So does among the modern and traditional people. This research aims at understanding the meaning of space in the residence of Java Tondano People in Minahasa. To achieve this objective, three important elements of residence must be considered, which are; setting, activities, and values. Bottom up approach is taken to reveal the meaning. The method of data collection and analysis are through triangulation of literature review, field observation, and interview. Case study implemented on the residences that Jaton People built within the period of 1900-1950, which historically show the characteristics of Minahasa traditional house. The result of the analysis suggests that the space in the house of Java Tondano people is not only a place to have a family, but also an integrated part of the Java Tondano people to preserve the value of community, to build relation and to maintain the harmony with the surrounding community. Such meaning of space is motivated by the value of appropriateness, tradition, and goodwill.
\end{abstract}

Keywords Activity, Meaning, Space, Setting, Value

\section{Introduction}

The aspect of behavior and cultural diversity will determine the different types of activities and setting [1, 2]. Therefore, the interpretation of a certain thing could be profoundly different in terms of different cultures or groups of the community [13]. Three main things could differentiate the objectives of culture: lifestyle, human mental aspect, habits, and different compatibility towards the environment. Lifestyle refers to the way of life chosen by a human, and that is based on goals, rules, regulation, daily behavior, values, etc. [18]. People try to fulfill specific values in life, such as securities, happiness, and togetherness. These values guide people in how they behave [14]. Value as the guideline of activities, the environment is understood as a system setting. Users select activities guideline; in other words, system setting enables a particular use of activities guideline. In the relation between the system setting and the people's actions, the meaning of a guided environment could be revealed [3]. Paragraph: use this for the first paragraph in a section, or to continue after an extract.

About the meaning of house or residence, it was discussed in a number of sources from various literatures/researches: house as a center of emotional intimacy, and ownership meaning [2]; house as the base of 
activities [20]; house is meant to be an important site of cultural activities and expression [7]. Furthermore, the house is seen as something dynamic [5, 33]. Such research related to the interpretation of space in the house especially about the social-spatial of Iraq traditional house [6]; the meaning of public space of Javanese traditional house [31]; the meaning of space in Taneyan Lanjang in Madura [15]. Based on those researches, it could be concluded that houses have different meanings. Meaning is not merely related to physical structure, such as providing a place to live, but also for social process and the activities occurring around it, however, there have not been any research about the meaning of space in the context of Java-Tondano (Jaton) people, as a community derived from the mix of Javanese and Minahasa tribes.

This research aims to reveal the meaning of space in the house of Javanese-Tondano in which established within the period of 1900-1950, wherein this period, the house of Jatonese still had their specialty of being Minahasa ethnic house [8]. Similar architecture can be interpreted differently by a different group of people/culture [13, 26].

The benefits of this research are first to give new understanding about the meaning of space; second, to provide an alternative in how to read the meaning of traditional houses, using bottom-up approach; third, to give inputs to all stakeholder regarding with the spatial design to remain always based on the local values.

\section{Theory and Methodology}

\subsection{Culture and its Components}

Culture plays a different role through different mechanisms. The interpretation of intimacy is different in terms of culture. Personal privacy, spatial privacy, rules and behavior, different habit, and interaction in culture during a specified period are categorized as cultural variables. Different culture considers different indicator to evaluate the culture. The indicator could be formed based on the level of individual and community, schemata, and the mental map, goals, legalistic, habits, and lifestyle [6].

Regarding cultural variables, Rapoport has confirmed that culture is too broad and abstract, that to be able to understand the entire cultural structure and its influencing factor towards the guided environment, it needs dismantling [26]. The idea of culture is too abstract, it could be understood from the more concrete social expression, and it has the potential to be observed, such as intimacy, social structure, social relation, etc while broad culture needs to be identified to reveal a more specific direction of expression through word view and value to the lifestyle and activities. Through an investigation of social expression of culture such as intimacy, household structure, social relation as well as the role of the institution, the influence of values, or cultural activities within the guided environment, the meaning could be measured [22].

\subsection{Setting System and Activities System}

Dwelling as a 'setting system where the activities system takes place' [23]. Activities system related to its function needs to be analyzed through four components: the activities itself, how the activities are carried out, how the activities are associated with other activities and the meaning of activities', as the latent aspect [25]. According to Rapoport [25], the situation, rules, and the behaviour are communicated through the signs occurring within the setting, so that the activities and setting are connected through meaning. Furthermore, it is explained that the meaning does not only become an important aspect of the function but it also becomes the most important function since the specific activities system directs it to the specific attribute setting and the environment explains the reason of its diversity as the result and the relation between culture and environment. Therefore, to investigate the meaning of occupancy, the three elements must be taken into account: 1) setting system, 2) activities carried out within, and 3) values appointed for both setting and activities [22].

Situation, role, and the sustainability of the behavior are still communicated by signs within the setting conceptualized through fixed feature elements (building, floor, wall, etc.), semi fixed-feature elements ("furniture," interior, exterior), and non-fixed feature elements (human, all activities and behaviors). The setting does not merely guide the behavior through non-fixed feature elements, or principally through fixed feature elements but also through semi-fixed feature elements giving important signs; the most important appearance of other activities and the behavior is through signs [22]. The similar room could further be different through the change of semi-fixed elements and various activities of the occupant.

\subsection{Value and Meaning}

Value could be understood as objectives, which consciously or unconsciously functions as criteria in all activities that carry cognitive, affective, and behavioral aspects [30]. The central role of the values within the human cognitive system came from three types of human needs: first, is from the individual need as the biology system; second, is from the charge determined by coordinated social interaction and third is from the charge of the function and the group survival. Such human basic needs come from ten universal motivation values [30]: 1) Self-direction: the need to be able to be independent in terms of thought and action; 2) stimulation: the need to have variation and stimulation; 3) Hedonism: the need for pleasure; 4 achievement: the need for personal success through competence shows the appropriateness with social standard, 5) power; the need to differentiate status to maintain a certain dominant position; 6) security: the need 
to have saved, harmonious and stable community, including good health, cleanliness, and taste; 7) Conformity: the need not to be harmful with others or the need not violate social expectation; 8) Tradition; the need to respect and commit to sharing experience and fate; 9) Benevolence; attention for others prosperity; 10) Universalism; attention for the prosperity for all and nature. The type of value of self-direction, stimulation, hedonism, achievement, and power are the values, which serve individual interest placed on the left side of the circle. Benevolence, tradition, and conformity serve as collective interest. Universalism and security serve both interests. Therefore they are located on the border of transition between the individual and cooperative group on the circle.

Regarding these universal values, there are ten general meaning categories of the home that constitutes a more specific manifestation than of universal value [16]. Those ten general meaning categories of home are [4]: 1) Home as security and control; 2) Home as a reflection of one's ideas and values; 3) Home as acting upon and modifying one's dwelling; 4) Home as permanence and continuity; 5) Home as relationships with family and friends; 6) Home as center of activities; 7) Home as a refuge from the outside world; 8) Home as indicator of personal status; 9) Home as material structure; the concrete physical dimension of the home; 10) Home as a place to own. The combination of types of universal and category values of the home is explained in Figure 1. In this figure, it is described that a home is directly connected to the type of value. However, the value of stimulation, universalism, tradition, and conformity are not clearly connected to one single meaning. The possible explanation is that because such type of value is more on how people see the community and how people think the community expects them to behave. Such a domain occurs when social interaction in the environment is seen. Yet, according to the general meaning of home is in harmony with the type of value and connected to the individual and collective interests [4].

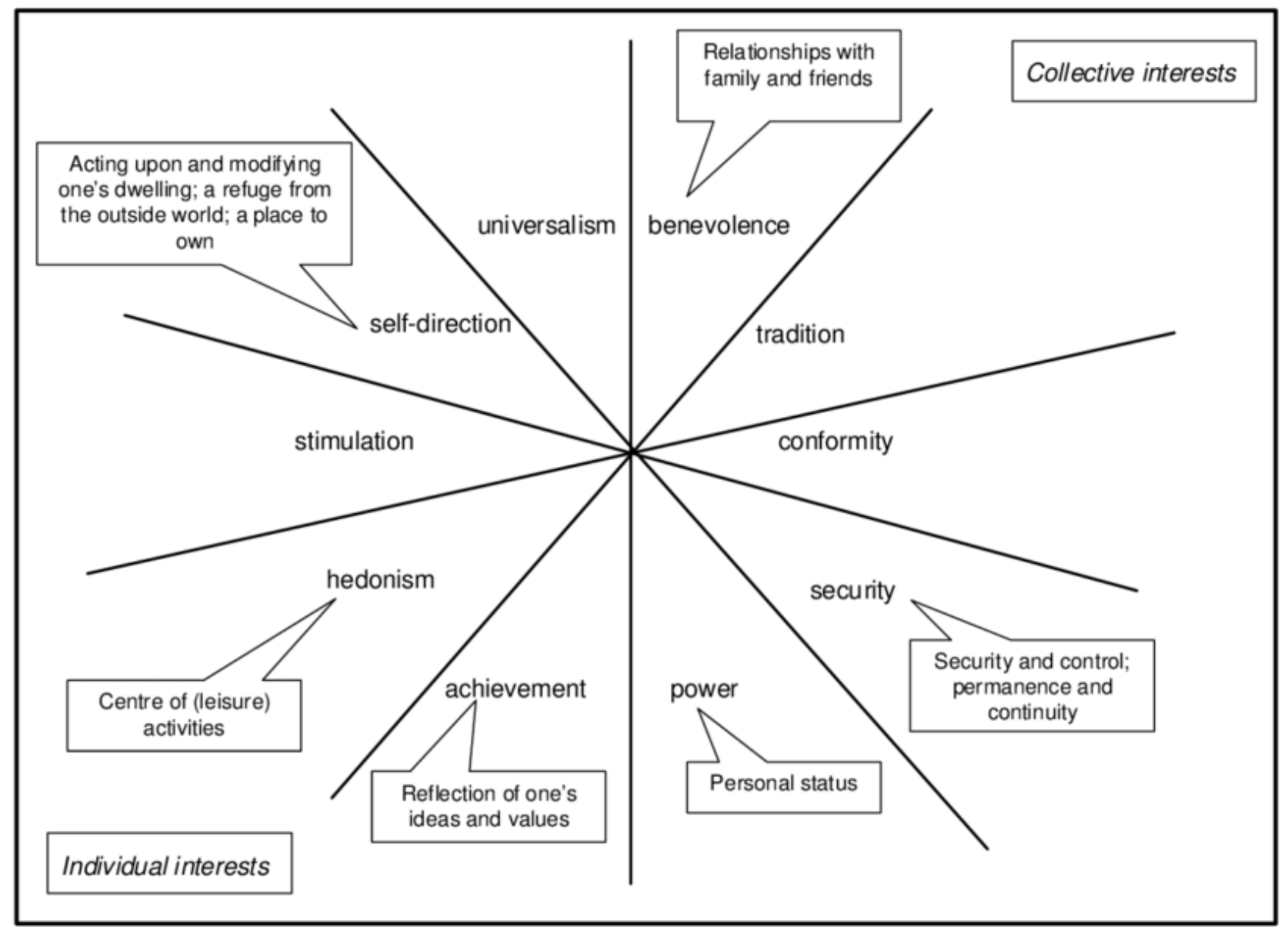

Figure 1. Structure within the Value and the General Meaning of Home (Meesters, 2009) 


\subsection{Meaning Reading Framework}

Exploration of meaning is done by using a conceptual framework called means-end chain [11]. Means-end chain is a model that tries to link the results of human choices to the values and goals that underlie the choices built based on Rapoport's theory [16]. The conceptual framework (means-end chain) can be understood as bottom-up where the entry point starts from the setting so that the sequence is setting-activity (consequence)-value. Exploring meaning can also start from 'consequences' which focuses on what people want to achieve as a goal structure approach, which is structurally understood as middle-out, the entry point starts from activity (consequence) so that the sequence is activity (consequence)-setting-value [17]. This approach is then called the approach in Laddering (Figure 2) [27]. The most important assumption for the framework is that the built environment in this case the residence is considered a system setting where the activity system takes place. People pursue certain values in life to guide their activities $[4,24]$.

\begin{tabular}{|l|l|}
$\begin{array}{l}\text { 3) Value } \\
\text { (meaning, e.g. relaxation) }\end{array}$ & $\begin{array}{l}\text { 3) Value } \\
\text { (meaning, e.g. relaxation) }\end{array}$ \\
$\begin{array}{l}\text { 2) Consequence } \\
\text { (activity, e.g. watching TV) }\end{array}$ \\
$\begin{array}{l}\text { 1) Attribute } \\
\text { (setting, e.g. living room) }\end{array}$ \\
Bottom-up
\end{tabular}

Figure 2. Means-end chain (bottom-up) and Goal structure (middle-out)

\section{Materials and Methods}

In this study, a naturalistic qualitative method with case studies was used to build a comprehensive understanding between humans and their homes in order to find the meaning behind their homes. The analysis was carried out by 'triangulation' [10]. The sample selection was carried out by purposive sampling, where the main criteria referred to houses built in the 1900-1950s period. In this period the house still characterizes the Minahasa ethnic house. From purposive sampling, 25 houses were selected as samples, with 40 respondents; 25 respondents from home owners and 15 respondents from historians, traditional leaders, religious leaders and elderly people who have experienced past events.

Data collection was started with a literature search to find the characteristics of the houses and past Jaton culture. It then continued with field observations on 25 houses to match the residential features obtained based on the literature. Furthermore, interviews were conducted with homeowners to complete residential features that were not observed in the field which may have been lost, demolished or changed. At this stage, technical triangulation analysis was carried out, namely analyzing residential features by cross-checking through literature, and performing field observations and interviews. The results were then reconstructed to obtain a comprehensive picture of the physical form of the houses of the Jaton people in the past.

The reading of the meaning was done bottom-up, in which the entry point started from the occupancy/setting feature so that the sequence was setting-activity (consequence)-value. Therefore, setting, activities, and values in this research were observed through indicators: 1 ) setting: obtained from observing the setting of element fixed features as such wall, floor, ceiling, stairs, door position and the setting of element semi-fixed feature [22]; the setting was observed within the organization of space through differentiation of category of space, position, sequencing, isolation, and integration activities [12]. 2) Activities: obtained through observations and interviews regarding basic domestic activities (cooking, eating, sleeping, bathing, washing, and storing) [29], religious tradition activities, community activities, and indigenous activities related to the lifecycle. The activities were distinguished by time (day/night, weekly, monthly, annually); actors (men/women, elderly/children, figure/public in general); the level of privacy (personal/collective, family members, guest/relatives). The identification of activities was performed to recognize the reasons (consequences) behind the activities. 3) Value: this indicator will be interpreted through the features of occupancy/setting and consequences. This interpretation was obtained through 40 respondents who were interviewed in depth and openly in order to gather as much information as possible. Furthermore, a descriptive analysis and discussion was carried out to connect people's behavioral choices to the underlying values, which caused the Jaton people to choose/set certain attributes in their homes. Therefore, the use of attributes has the consequence of helping to fulfill certain values. The results were returned to 15 respondents, namely to traditional leaders, religious leaders, historians and old people who experienced events in the past to interpret the meaning contained in each value and then agreed on it. At this stage, triangulation of sources was carried out, namely the validation of meaning through different sources of information. The final result was concluded/interpreted by the researcher through the structure of universal values and meanings $[4,16,30]$ (figure 1 ).

\section{Results and Discussion}

The settlement of Jaton community is better known as 'Kampung Jawa Tondano', which is one of the old villages in Minahasa, precisely located in Sub-district Tondano, 
District Minahasa, Province North Sulawesi. Kampung Jawa Tondano constitutes through historical events. The people of Jawa Tondano are the community that came from the historical event of Diponegoro war, which caused Kyai Modjo. His followers from Java were exiled to Manado (Minahasa). There, they married the Minahasa women, and the result of such marriage between 'Javanese' men and 'Minahasa (Tondanese)' women is better known as 'Jaton'. They then grew up and raised in Tondano as Moslem community whose belief is very different from the environment where they live [19].

According to Graafland [9], at the beginning of their arrival, Jaton people built houses resembling Minahasa typical houses (Figure 3). As farmers, their houses are shaped that resembled a stage, which clearly differentiates the function of the spaces vertically. The space underneath the house serves as storage of farming equipment and cages for their livestock; the middle room was used as the place they live and the soldor (loft) as a place to store and the dry paddy (Figure 4). Horizontally, the middle space/stage space consisted of setup (porch), pores (living room), bedroom, dining room, and nawu (kitchen). Behind outside the kitchen, there were some other servicing rooms, such as cleaning room, dodoku (bridge), and parigi (well). Meanwhile, the toilet was placed separately far away from these rooms. The differentiation of spaces, which occurred because of its activities was categorized based on the characteristic of the space; they are public spaces as the space where everyone could gather in the upfront areas consisting of setup and poers, private spaces consisting of bedrooms in the middle section, and servicing spaces such as kitchen, cleaning room, wells and toilet in the back area as well as spaces to store the farming product and farming equipment were underneath the house. There is a loft (soldor) as a place to dry up and store paddy and corn (Figure 5).

The discussion about spaces in this paper would be limited to discuss setup, pores, bedrooms, and kitchen, as the most specific areas influenced by the culture of Jaton people.

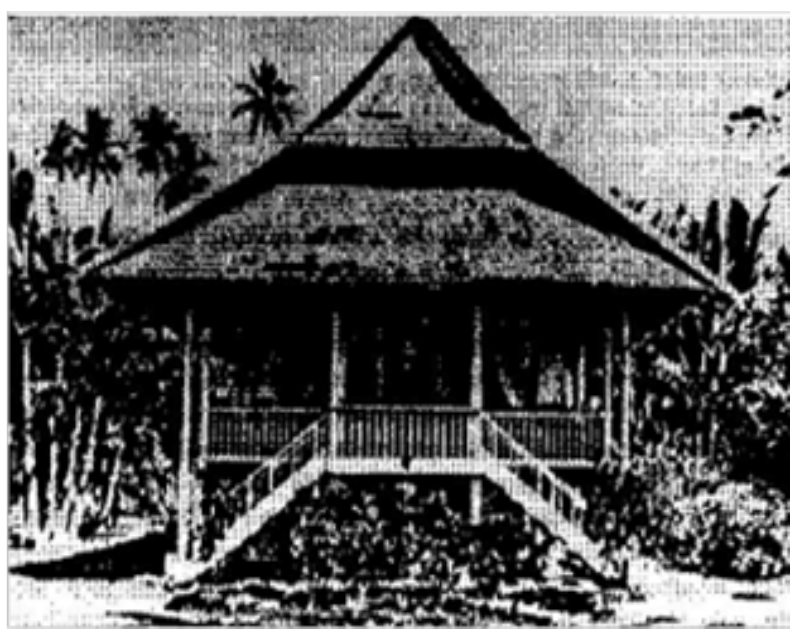

Figure 3. The House of Minahasa Ethnicity [32]

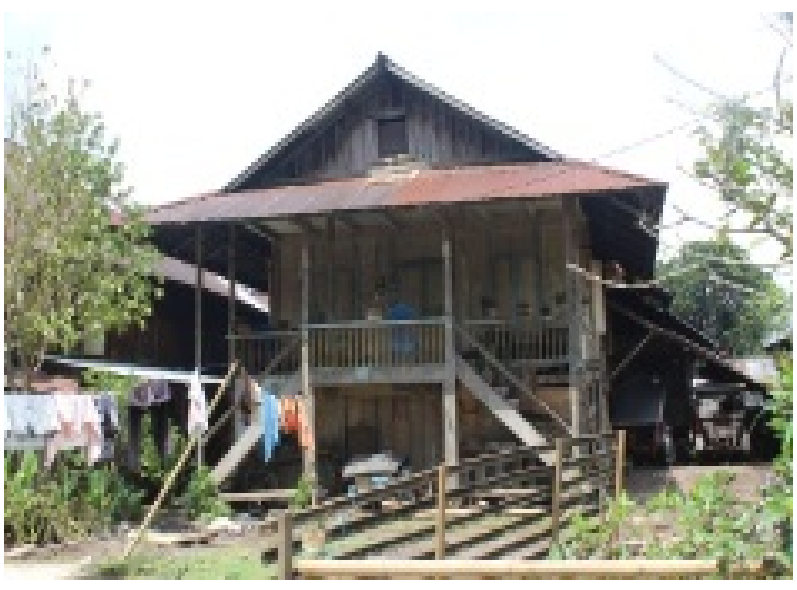

Figure 4. The House of Jaton People (Field observations, 2018)
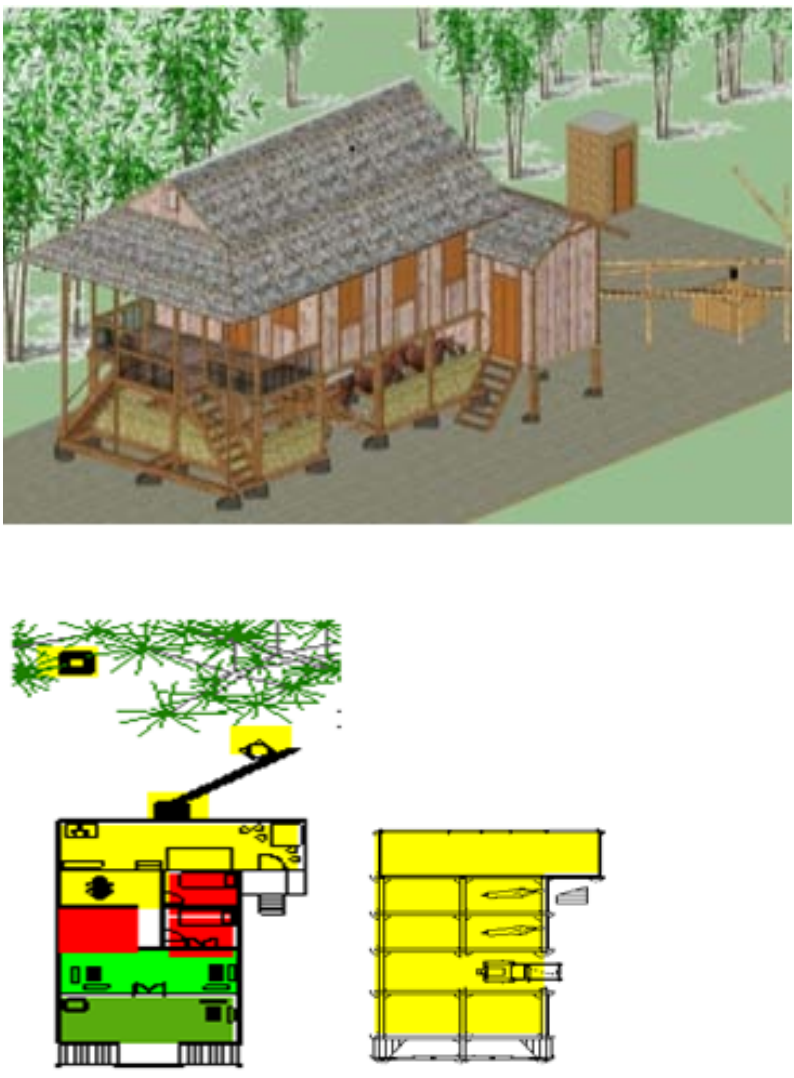

Stage floor

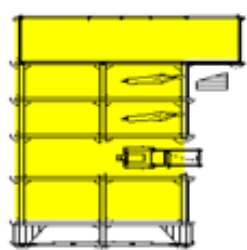

Floor Underneath (soldor)

Service (kitchen, cleaning spot, well, toilet)

Private (Bedroom) well, toilet)

\section{Public: Pores (living room)}

Public: Setup (porch)

Figure 5. The Form and Spaces of House of Javanese Tondano People based on the Analysis of "Triangulation” (Field Research, 2018) 


\subsection{Setup (porch)}

The house of Javanese Tondano in the past was very identical with a wide-open porch (setup). Once they finished their farming activities in the afternoon, the setup (porch) was used as a place to relax/gather with the rest of family members, interact with relatives/neighbors, accepting informal guests, having light talks with the member of mapalus (farming group) about things related to their farming business. This space could also serve as a place to practice silat (traditional martial arts)/dance samra for teenagers (Figure 6a). Besides informal activities, setup could also be used to accept guests on formal events, either happy events or sad ones (Figure 6b). According to respondents, the wide space of dimension shows the openness of Jaton people in receiving everyone who comes. It was shown by the position of the house that faced the street and that there were two stairs to separate the circulation of those who went up and those who went down at formal events (Figure 6). The position of setup facing the street enabled the people living in the house to greet everyone passing by.

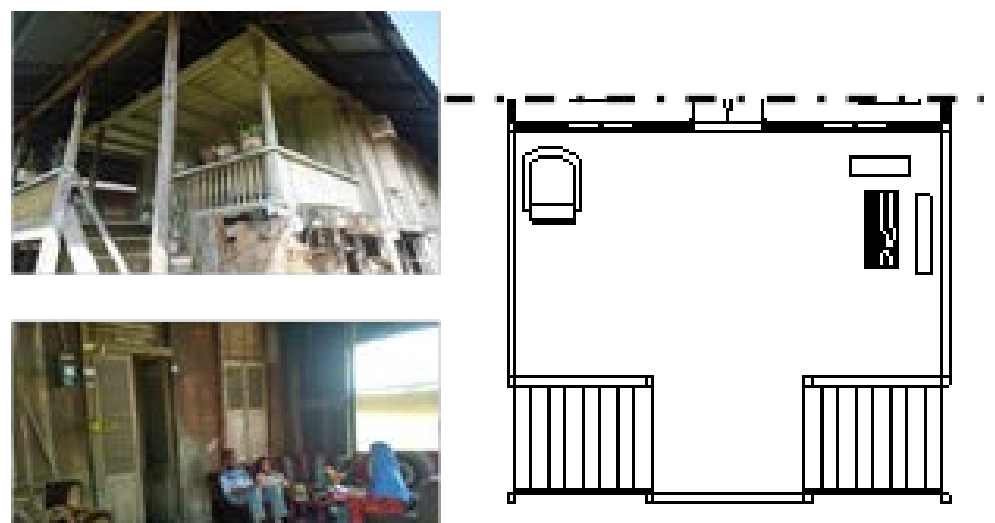

(a)

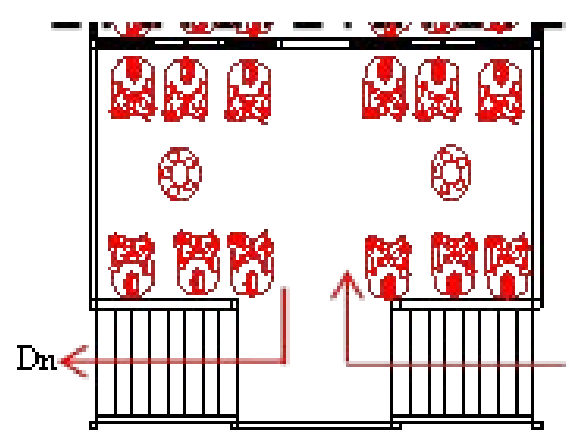

(b)

Figure 6. Setting System and Activities System in Setup (porch) (Field Research, 2018)

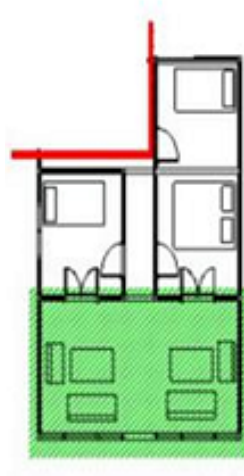

(a)

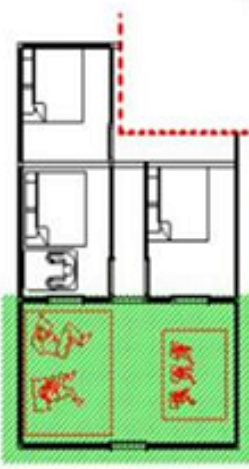

(b)

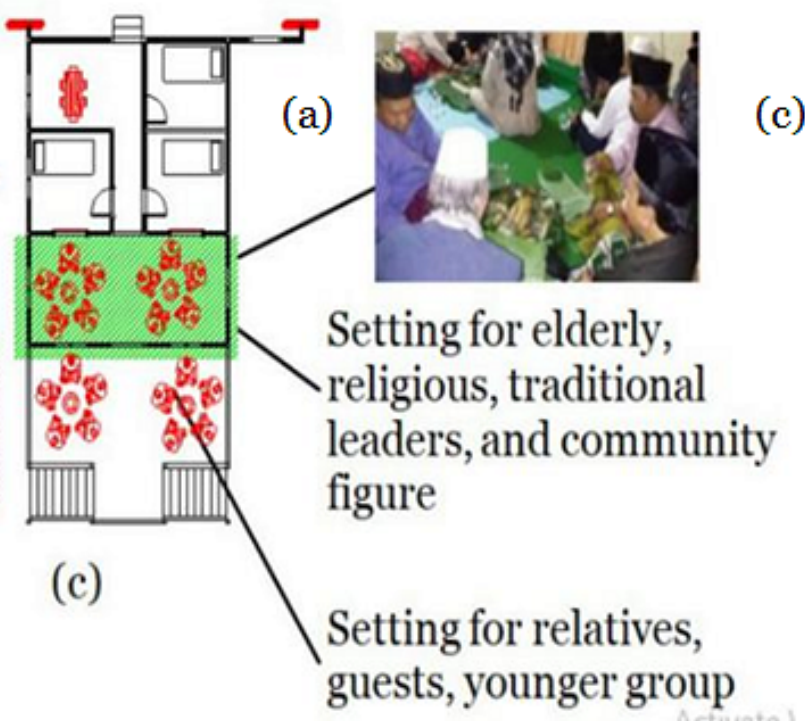

(c)

Figure 7. Setting System and Activities System in Pores (Living Room) 


\subsection{Pores (living room)}

Pores are upfront space as the first space entered after setup. This pore also serves as anon-segmented multifunction area. Space privacy is obtained through the setting of time. During the day, it is used as a place to receive formal guests (Figure 7a); to have a meeting with elder people with private objectives as a series of traditional procession, and other activities such as religious activities, custom (regarding with the lifecycle), and other civil activities (social gatherings, etc.) which ran weekly, monthly, annually and contemporary.

Religious and indigenous leaders claimed that besides play role to guide family member, these activities also play role to grow the sense of togetherness as well as to embed the religious values, respect each other, appreciate each other, make good examples, and being together with Jaton people as the heritage from their founding father.

There is a setting of the actor in using pores and setup space in some certain formal activities. Elderly, religious, traditional leaders, community figures, and indigenous figures take pores area, while the younger generation, relatives, and other guests take setup (porch) [Figure 7c]. Therefore, from this set of elements, it can be seen that there is a value of respect in terms of actor set. Besides, the actor setting, there is also an eating setting in such formal events, by sitting down cross-legged on the floor surrounding ambeng. An ambeng is surrounded by 5 to 6 people. Such an eating setting contains symbolic meaning, the number 5 (five) as Islamic principles, while 6 (six) as the faith principles. Such a setup could easily be done in a space with less furniture. In the evening, the pores served as a standard room, to recite Al-Quran and as a bedroom for children/relatives (Figure 7b). Before going to bed in this room, grandmother told stories about prophets and the history of how their ancestors arrived in Minahasa. According to respondents, such routine is performed by elders every evening to foster the spirit of fighting or struggling in their kids as well as to embed the values of religion. As a multifunction room, this room is the most integrated room with other rooms, such as to setup, bedrooms, and kitchen areas (Figure 8).
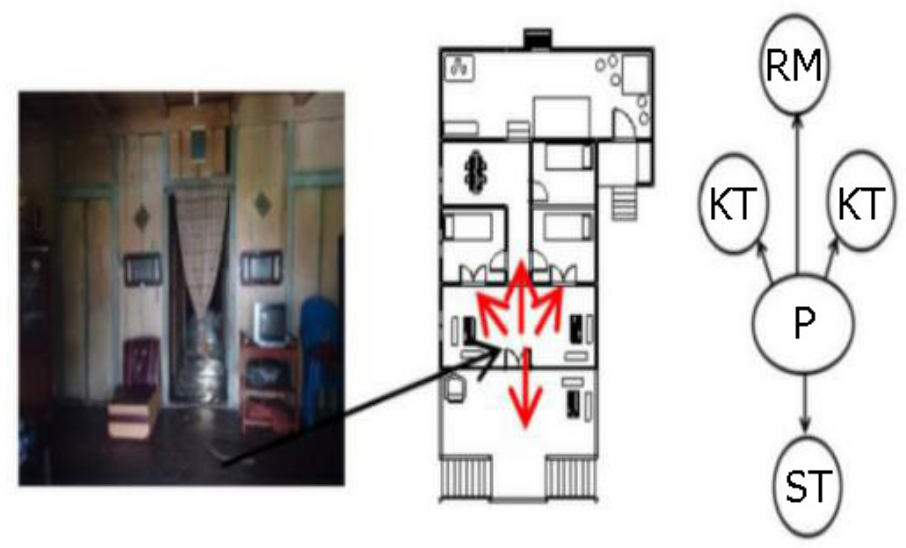

ST $=$ Setup

$\mathrm{P}=$ Pores

$\mathrm{KT}=$ Bedroom

RM= Dining Room

Figure 8. Room Integration in Pores Area (Field Research, 2018)

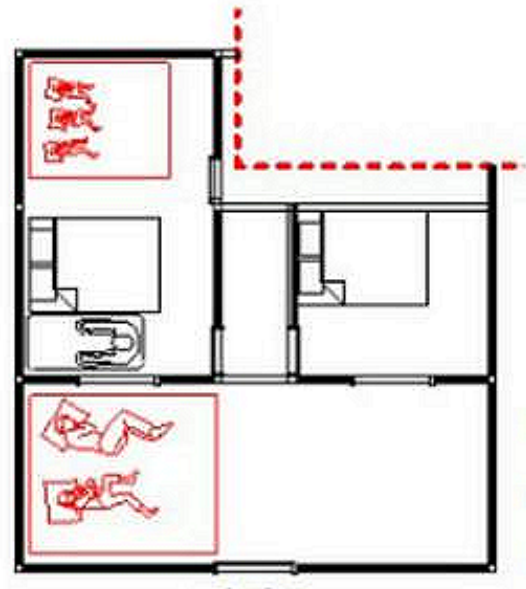

(a)

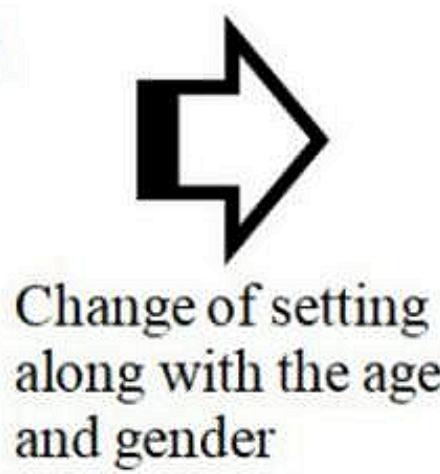

Change of setting along with the age and gender

Figure 9. Setting System and Sleeping Activities (Field Research, 2018)

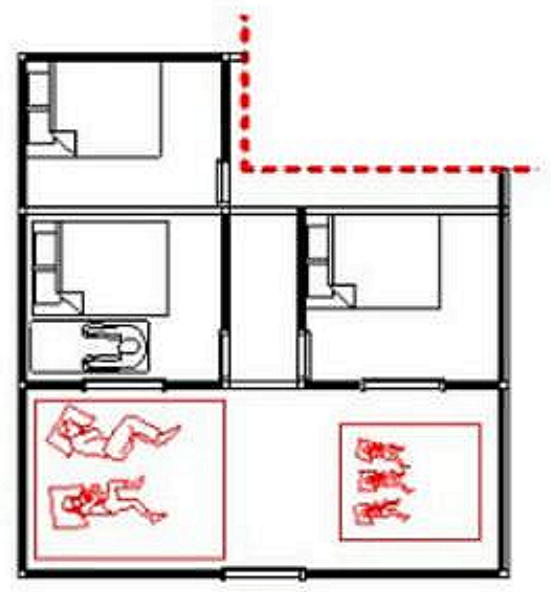

(b) 


\subsection{Bedroom}

Initially, bedrooms in the houses of Jaton people only consist of 2 units. Between these two bedrooms, an aisle separates them, which leads to the dining room and kitchen. One larger bedroom-sized $2.25 \mathrm{~m} \times 3.25 \mathrm{~m}$, as the main bedroom for the elderly with their little children, while other relatives sleep in pores (Figure 9a). Another bedroom has a size of $2.25 \mathrm{~m} \mathrm{x} 2.25 \mathrm{~m}$, and it is used by their grandmother. Circumcised boys sleep separately from their parents. The girls sleep separately with their parents by dividing the bedroom into 2 parts; the girls in the front part while the parents in the rear section. While the boys sleep in the pores with other (Figure 9b), for Jaton people, children who live together with relatives give them another value of happiness for the parents, that at an early age the children are introduced to their relatives as a form of togetherness, harmonious life should be established at an early age. Frequently, the people of Java Tondano allow their children to stay with their uncle or aunt.

When a girl has got married, they are free to choose to live with their parents or if they could afford a house around their parents', while the boy, once they are married, they usually live with their wife in his wife's parents (parents-in-law). This shows that the household of Jaton people extends family which does not only consist of the core family, yet a house consists of parents, grandparents, and other relatives; therefore, the differentiation of bedrooms category frequently occurs along with age, and it is influenced by the gender and kinship. About the sleeping position, it is abstinence for Jaton people in the past to sleep with the head heading the North and the feet to the South since for them such position is similar to the position of the buried dead body. Other than this position, people are free to choose what position to sleep and the most important thing is that they pray before bed and lay down facing to their right side. Therefore, it is normal that sleeping also influences the bedroom set. Figure 9 shows the change of setting in the sleeping activity.

Bedrooms as private rooms are bordered by massive walls. There are two doors in each bedroom-one to the pores and another to the aisle. According to the respondent, the door leading to the pores aims to enable controlling the activities happening in pores in certain formal events in order to prepare food, while the door leading to the aisle has a control function for the girl who uses the bedroom at the front part (Figure 10). The walls bordering the bedroom with pores, and dining room causes the bedroom to have the strongest isolation level among other rooms. Cosmologically, there is no rule determining the position of bedroom related to the environment/nature and its connection with other rooms, rather it is because of the setting for controlling function and privacy for the elderly.

\subsection{Nawu (kitchen)}

The position of the kitchen as a service area is located in the rear area of the house of Jaton people. The observation and interview reveal that the position of kitchen, where the female family members spend most of their time to prepare food for the family could be accessed from the side door, which mostly facing the street; some respondents said that cooking is the female domain which is considered as inappropriate to be seen directly from the main door so that it needs a special access to go to. Therefore, it is not appropriate to double the function of the kitchen as a dining room to serve guests. As historically noted, farmers spend most of their time on the field so that they do not have much time for a formal setting. Nevertheless, there are many contrary practices with the presence of the door facing the kitchen located in line with the entrance door.

According to respondents, this position contains an expectation that the door straight from the front up to the rear heading to the kitchen enables the sustenance to easily enter the house through the front door and it could easily be stored by the kitchen that provides isolation level from the front area to the kitchen. However, it could still realize the expectation that the kitchen is a symbol of sustenance. It is different from the belief of Minahasa people that spirits have straight pattern, that with such open setting, the spirit would coincidentally "strayed" into the house through one of the opened doors, would directly go out through other opened door facing the one they previously entered. This is also a reason uttered to explain the background of the pattern in locating the stairs facing the porch in front of traditional Minahasa house [28]. This reason is contrary to the motivation/expectation of Jaton towards the setting. It strengthens what was said by Lawrence that similar architecture has different interpretations by different groups of people or cultures [13]. 


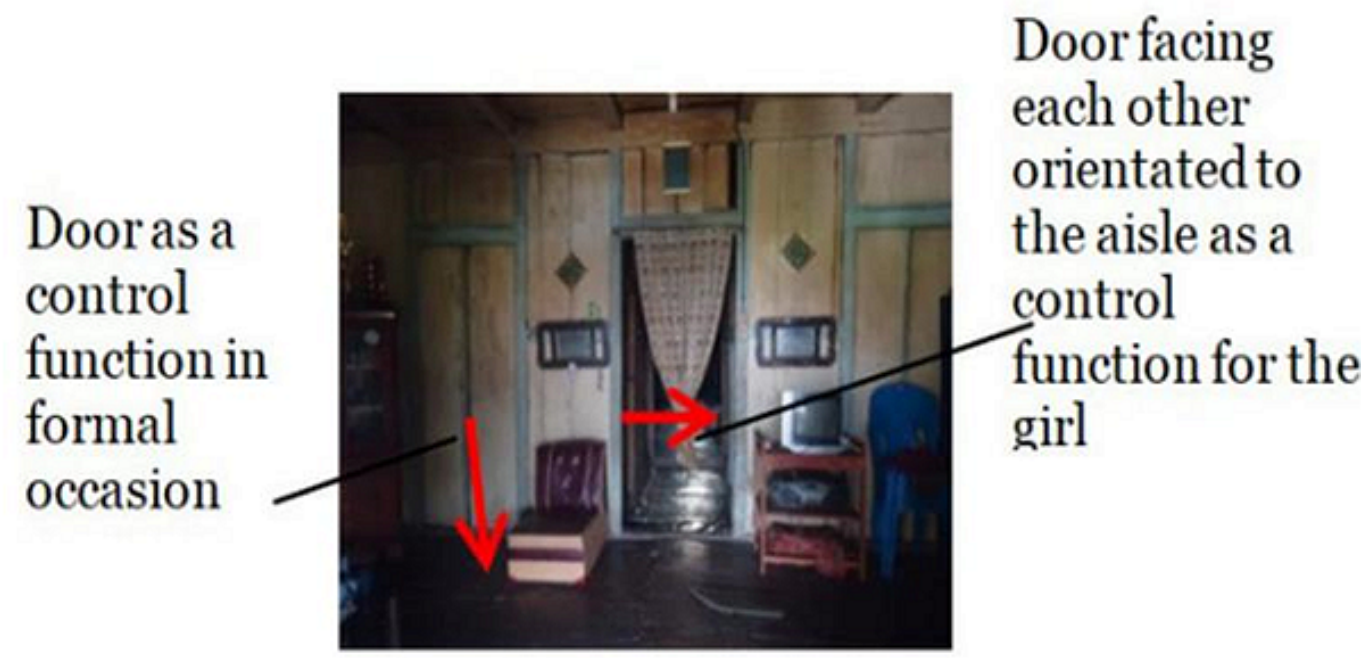

Figure 10. Position of Bedroom Door as a Control Function (Field Research, 2018)

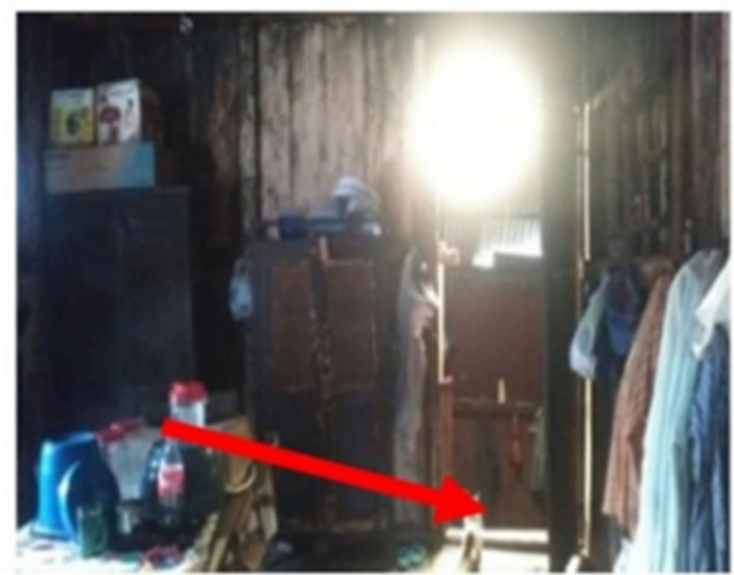

The view from the dining room to the kitchen area with the lower floor level than the dining room

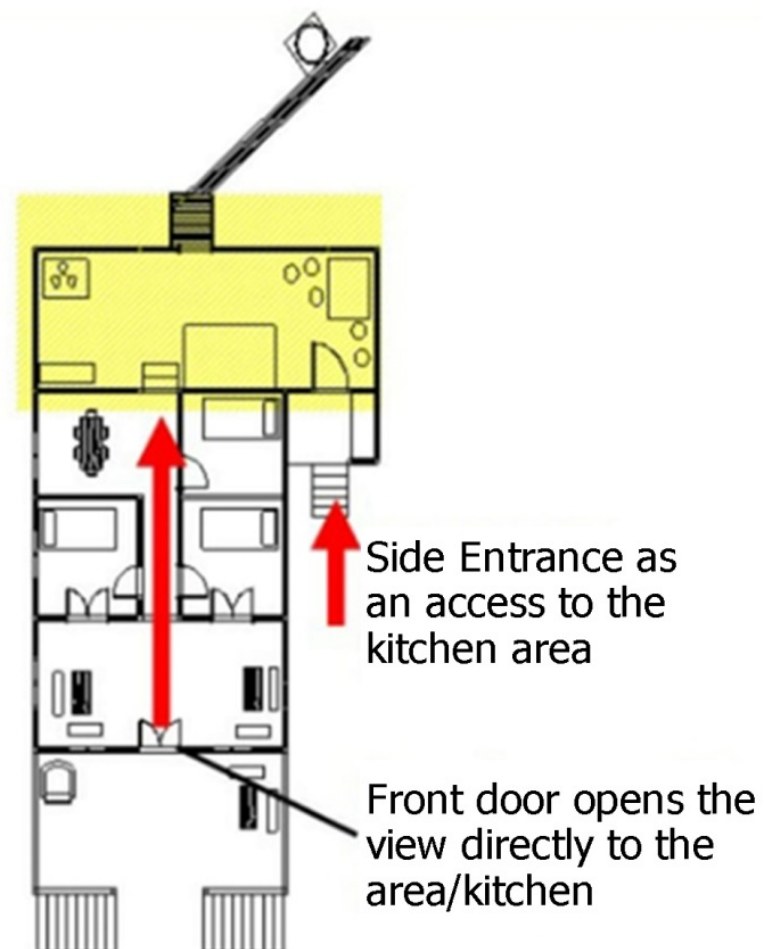

Figure 11. The Position of Kitchen in the Deepest Area in Room Sequencing (Field Research, 2018)

Differentiation of space in the house of Jaton people, especially on the stage floor, is basically motivated by the will to acquire privacy, even though there are multifunction spaces, yet, the privacy is set based on the time (day-night). It is clearly shown by the use and the element set to separate the room, such as wall, curtain, floor level, stairs, and activities/behavior setting. Other than the use and the setting of element fixed feature and semi-fixed feature, the level of space privacy are also obtained from sequencing room from the front to the rear based on the characteristic of the activities. Public activities such as gathering, socialization take place in the front part, private rooms in the middle part, and service areas in the rear part. The willingness to enable access to the pores as the common room allows the room to be integrated with other rooms such as the bedroom, aisle connecting the kitchen, and the porch. On the contrary, to have an isolated room, it could be obtained by using separators such as walls to obtain a high level of isolation in bedrooms. In contrast, for the kitchen area, the use of a curtain as a flexible separator, the isolation level is obtained based on the motivation wanted. Based on the above discussion, when it was grounded on 
the structure of value (Figure 1), then what underlies the people of Jaton in behaving within their houses was motivated by the value of 1) Conformity: the need not to violate social expectation, it is shown in the room setting, such as the setting of bedroom position to obtain the control function, the bed setup, room sequencing to obtain the level of privacy just like in the public area, private and service; 2) Tradition; the need to respect and to commit to sharing experience and fate; it is shown in the room setting to obtain the integration of pores room as the common room in formal occasion, religious activities, tradition related to lifecycle, social activities), sleep together with relatives, etc.; 3) Benevolence; pay attention to other people's prosperity, shown through the position of setup (porch) orienting to the street to enable them greeting the people pass by, the wide room is used as a room to socialize/to interact with relatives, neighbors, social activities, etc. The three values provide the meaning of the house for the people of Java Tondano not only as of the place to guide the family but also as an integrated part of the Java Tondano people to keep embedding the values of harmony.

\section{Conclusions}

The following things are concluded based on the findings and discussion in this study. Those are: First, space for people of Jaton is not only as a place to guide the family, but also as an integrated part of the people of Java Tondano to keep embedding the values of harmony, establishing relation and to keep in harmony with the environment, motivated by benevolence values, tradition, and conformity. Those values are obtained through elements setting of fixed feature, semi-fixed feature, and non-fixed feature. In organizing the space elements, it could be observed through the differentiation of the category of rooms, the position of rooms, sequencing, isolation, and room integration. Second, the use of the bottom-out approach is proven to reveal the meaning of traditional houses with the reading of its element setting obtained through 'triangulation' method.' Third, the understanding of the rooms in Jaton house provides inputs for the stakeholder regarding the room designing that should take local values into account in designing rooms of contemporary houses.

It is expected that the results of this study can inspire others to conduct similar research to uncover specific cultures in traditional homes, especially in revealing the meaning of space. More specifically with this research, it will be a motivation to carry out further research on Jaton community houses outside the Minahasa in an effort to uncover Jaton's core culture in their homes, where new settlements are obtained so that the characteristics of the Jaton community become manifest local wisdom of the people of Jaton.

\section{REFERENCES}

[1] Altman I., "Territorial Behavior: Conceptual Issues,” in The Environmental and Social Behaviour: Privacy, Personal Space, Territory, Crowding, Brooks/Cole Publishing, 1975, pp. 1-256.

[2] Buttimer A., Seamon D., "Home Reach and the Sense of Place,” in The Human Experience of Space and Place, Routledge Revivals, 1980, pp.1-204.

[3] Chemero A., "An Outline of A Theory of Affordances," Ecological Psychology, vol. 15, no. 2, pp. 181-195, 2003. DOI: $10.1207 / S 15326969 E C 01502 \_5$

[4] Després C., “The Meaning of Home: Literature Review and Directions for Future Research and Theoretical Development,” JSTOR, vol. 8, no. 2, pp. 96-115, 1991.

[5] Dovey K., "Home and homelessness," in Human Behaviour and Environment, (Altman I., Wohlwill JF. ed), Plenum Press, 1985, pp. 1-339.

[6] Foroutan M., Hosseini A., "The Socio-Spatial Meaning in Traditional Houses of Arak," Journal of Applied Environmental and Biological Sciences, vol. 4, no. 4, pp. 108-117, 2014.

[7] Gauvain M., AItman I., Fahim H., "Homes and Social Change: A Cross-Cultural Analysis," in Environmental Psychology: Directions and Perspectives, (Feimer NR., Geller ES. ed), Praeger, 1983.

[8] Gosal PH., "Morfologi Arsitektur Rumah Tradisional Minahasa," [Architectural Morphology of Traditional Minahasa Houses] Temu Ilmiah IPLBI, Manado, Indonesia, Oct, 2015, pp. 145-152.

[9] Graafland N., "De Minahasa: Haar Verleden En Haar Tegenwoordige Toestand” [Minahasa: Past and Present], M. Wyt \& Zonen, 1898.

[10] Groat L., Wang D., “Architectural Research Methods”, John Wiley \& Sons, 2013, pp.1-461.

[11] Gutman J., “A Means-End Chain Model Based on Consumer Categorization Processes,” Journal of Marketing, vol. 46, no. 2, pp. 60-72, 1982. DOI: 10.2307/3203341

[12] Hanson J., "An Introduction to the Study of Houses," in Decoding Homes and Houses, Cambridge University, 1999, pp. 1-318.

[13] Lawrence RJ., "House Form and Culture Re-Examined," in Housing Dwelling and Homes, Design Theory, and Practice, John Willey \& Sons, 1987, pp. 1-319.

[14] Lindberg E., Hartig T., Garvill J., and Gärling T., "Residential-Location Preferences Across the Life Span," Journal of Environmental Psychology, vol. 12, no. 2, 1992, pp. 187-198. DOI: 10.1016/S0272-4944(05)80070-2

[15] Tulistyantoro L., "Makna Ruang Pada Tanean Lanjang di Madura," [The Meaning of Space in Tanean Lanjang in Madura] Dimensi Interior, vol. 3, no. 2, pp. 137-152, 2015. DOI: 10.9744/interior.3.2 
[16] Meesters J., “The Meaning of Activities in the Dwelling and Residential Environment: A Structural Approach in People Environment Relations,” Delft University Press, 2009, pp.1-269.

[17] Pieters R., Baumgartner H., Allen D., “A Means-End Chain Approach To Consumer Goal Structures,” International Journal of Research in Marketing, vol. 12, no.3, Elsevier Ltd. pp. 227-244, 1995. DOI: 10.1016/0167-8116(95)00023-U

[18] Pourdeihimi S., “Culture and Housing,” Housing and Rural Environment, vol. 30, no. 134, 2011, pp.: 3-18.

[19] Pulukadang I., "Fakta Sejarah Kepahlawanan Kyai Modjo Sebagai Perintis Kemerdekaan Indonesia dalam Perang Jawa 1825-1830,” [Historical Facts of Kyai Modjo's Heroism as the Pioneer of Indonesian Independence in the Java War 1825-1830] Unsrat Press, 2017.

[20] Rakoff R., "Ideology in Everyday Life: The Meaning of the House,” Politics and Society, 1977, vol. 7, no. 1, pp. 85-104. DOI: $10.1177 / 003232927700700104$

[21] Rapoport A., “Human Aspect of Urban Form,” Pergoman Press, 1977.

[22] Rapoport, A., “The Meaning of the Built Environment,” Sage, 1982.

[23] Rapoport A., "Systems of Activities and Systems of Settings," in Domestic Architecture and the Use of Space (Kent S. ed.), Cambridge University Press, 1990, pp. 9-20.

[24] Rapoport A., “A Critical Look at the Concept 'Home',” in The Home: Words, Interpretations, Meanings, and Environments (Benjamin DNA., and Stea D., ed), Aldershot, 1995, pp. 25-52.

[25] Rapoport A., “Theory, culture and housing”, Housing, Theory and Society, 2001, pp. 145-165.
[26] Rapoport A., "Culture, Architecture and Design,” Locke Science Publishing Company, 2005, pp. 1-137.

[27] Reynolds TJ., Gutman J., "Laddering Theory, Method, Analyses, and Interpretation," Journal of Advertising Research, vol. 28, no. pp. 11-31, 1988.

[28] Rogi OHA., Wahy, "Identifikasi Aspek Simbol dan Norma Kultural Pada Arsitektur Rumah Tradisional di Minahasa," [Identification of Symbol Aspects and Cultural Norms in Traditional House Architecture in Minahasa] Ekoton, vol. 9, no.1, pp. 43-58, 2009.

[29] Schlyter A., “Time Series Analysis: A Longitudinal Study of Housing Quality in Lusaka" in Housing the Poor In the Developing World. Methods of Analysis, Case Studies and Policy (Graham TA., and G WK ed.), Routledge, 1991, pp.1-19.

[30] Schwartz SH., "Universals in the Content and Structure of Values: Theoretical Advances and Empirical Tests in 20 Countries," in: Advances in Experimental Social Psychology (Zanna MP., ed.), Academic Press, 1992 pp. 1-65

[31] Sumardiyanto, Antariksa, Salura P., "Makna Ruang Publik Pada Rumah Tradisional Masyarakat Jawa Kasus Studi: Desa Jagalan Kotagede Yogyakarta," [The Meaning of Public Space in Traditional Javanese Houses. Case Study: Desa Jagalan, Kotagede, Yogyakarta] Jurnal Arsitektur NALARs, vol. 15, no. 1, pp.1-12, 2016. DOI: 10.24853/nalars.15.1.1-12

[32] Supit B., "Minahasa dari Amanat Watu Pinawetengan Sampai Gelora Minawanua," [Minahasa from Mandate Watu Pinawetengan to Gelora Minawanua], Sinar Harapan, 1986, pp. 1-222.

[33] Werner CM., Altman I., Oxley D., "Temporal Aspect of Home. A transactional Perspective," in Home Environments (Altman I., Werner CM., ed), Plenum Press, 1985, pp. 1-339. 